\title{
HYGIENIC STATUS AND DETERMINATION OF SOME HEAVY METAL RESIDUES IN FROZEN CHICKEN IN ALEXANDRIA CITY
}

\author{
Amal, F.A. Mansour \\ Animal Health Research Institute Alexandria Branch
}

\section{ABSTRACT}

Fifty frozen chicken samples were collected from markets located in Alexandria city, and were subjected to Microbiological and Chemical examination. Bacteriological examination recorded mean values of total Aerobic Plate Count, Total Enterobacteriaceae and total Coliform counts of frozen chicken were $1.6 \times 106,3.3 \times 104$ and $1.3 \times$ 103 cfu/g respectively.

The incidence of Staph. aureus, Enteropathogenic E-coli and Salmonella species in frozen chicken samples were 20,16 and 6\% respectively. The $p H$ and $T V B-N$ were within the permissible limits. The examined samples had a normal values of cadmium ( $c d)$, lead $(\mathrm{pb})$, copper ( $\mathrm{cu})$ and Mercury $(\mathrm{Hg})$ (the mean values were 0.005, 0.0022. 0.954 and $0.085 \mathrm{mg} / \mathrm{g}$ Respectively) and were analized by Atomic Absorption Spectrophotometers. The Public health hazard of bacteria and heavy metal residues were discussed.

\section{INTRODUCTION}

Poultry meat comprises a substantial protein of Egyptian diet. The physical meat inspection in markets is based on visual inspection, which does not identify pathogenic microorganisms such as Salmonella, Enteropathogenic E-coli, or Staph. aureus Edwards et al. (1997). To 
improve the control of such pathogens via improvement in process hygiene we must apply the Hazard Analysis Critical Control Point (HACCP) system which has been promoted and implicated in the European union. This analysis allowed the identification in the process flow of the sensitive areas that might contribute to a hazard.

The slaughtering and dressing of broilers involve several different processes which influence the bacterial load of the carcasses (Sauter et al., 1968, Notermans et al., 1977). Aerobic plate count, Psychrotrophs, Coliform, Staphylococcus aureus and Yeasts and Moulds have been used in meat and poultry products to assess their microbiological safety, sanitation condition throughout processing and keeping quality (Tompkin, 1983; Lillard et al., 1984 and Lillard, 1990).

Heavy metals are potential environmental contaminations with the capability of causing human health problems if present to excess in the food we eat. They are given special attention throughout the world due to their toxic effects even at very low concentration (Das, 1990). Lead (Pb) is neurotoxic with varying symptoms. It is particularly toxic to the brain, kidneys, reproductive system and cardiovascular system. Lead is used in many industrial processes, Lead paint, lead gasoline, It is a common material for spraying fruit tree. Exposure to it can cause kidney damage, infertility, miscarriage and hypertension (Silbergeld 1996). Exposure of children to high levels may cause encephalopathy and /or irreversible mental retardation (Go yer 1996 ).

Cadmium is used extensively in the mining and electroplating industries and found in fertilizes and fungicides. Cadmium poisoning may result in a case called Itai-Itai or ouch-ouch disease which characterized by severe pain, soft bones and the death may occur as a result of renal failure (peter, 1993). Copper $(\mathrm{Cu})$ in an essential trace 
element for animal and man. It is released into the environment primarily through mining, sewage, treatment plant, solid waste disposal, welding and electroplating processes. It is a common component of fungicides and algaecides.

Agricultural use of copper for these purposes can result in its presence in soil, ground, water, farm animal, (ATSDR 1990). Acute toxicity of ingested copper is characterized by abdominal pain, diarrhea, vomiting, tachycardia and metallic taste in the mouth. Continued ingestion of copper compounds can cause cirrhosis and other debilitating liver conditions (Mueller-Hoecker et al. 1988).

Mercury was used as fungicides, mercurial fungicides used for seed dressing. Toxic compounds of mercury accumulate in animal tissues, the alkymercuries are slowly metabolized and more evenly distributed in the body tissue (Underwood, 1977). Mercury caused redness of lips, throat and tangue, loss of teeth, swelling and redness of the skin with pink red finger tips. It affects the nervous system causing irritability (Mert, 1987).

\section{MATERIALS AND METHODS}

\section{A- Sampling}

Fifty frozen chicken samples were collected from markets located at Alexandria city. The samples were transferred to the laboratory in an ice box without undue delay to be examined.

\section{B- Chemical examination}

a- Determination of PH value according to ISO (1974).

b- Determination of Total Volatile Basic Nitrogen (TVB-N) according to FAO (1992). 
C- Heavy metal analysis: Digestion: of samples was according to perez (1999), Determination of cadmium (cd), lead ( $\mathrm{Pb}$ ) and copper (cu) were conducted by using Atomic Absorption Spectrophotometer “AAS"(perkin Elmer 2380) according to Richard and Rubinshapiro (1986). In case of mercury, The analysis was conducted according to Honway and Donn (1985) using flameless atomic absorption spectrophotometer.

\section{C- Bacteriological counts:}

The samples were subjected to bacteriological examination through determination of:

a- Total Aerobic plate count by spreading technique using plate count agar incubated at $37^{\circ} \mathrm{C}$ for 24 hours according to European Union communities Commission (2001).

b- Total Enumeration of coliform bacteria count using lauryl sulphate tryptose broth incubated at $37^{\circ} \mathrm{C}$ for 48 hours according to $\boldsymbol{F A O}$ (1992).

C- Total Enterobacteriaceae count according to European Union Commumities Commission (2001).

\section{D- Detection of some food- borne pathogens:}

a- Isolation and identification of Staphylococcus aureus according to Bennett and Lancette (2001).

b- Isolation and Identification of salmonellae according to Health protection Agency (HPA) (2003 a).

c- Isolation and identification of Enteropathogenic Escherichia coli according to Health protection Agency (HPA) (2003 b).

Seriological identification was done by using diagnostic sera, (Biotec, 1999). 


\section{RESULTS}

Table (1): Mean Values of Bacterial Counts of the Examined Frozen Chicken Samples. $(n=50)$.

\begin{tabular}{|c||c||c|c|}
\hline \hline Samples & Aerobic Plate & Enterobacteriaceace & Coliform \\
\hline \hline Frozen chicken & $1.6 \times 10^{6}$ & $3.3 \times 10^{4}$ & $1.3 \times 10^{3}$ \\
\hline
\end{tabular}

Table (2): Incidence of Food Borne Pathogens in the Examined Samples ( $\mathrm{n}=50)$.

\begin{tabular}{|c||c||c||}
\hline Isolated Microorganism & $+\mathbf{V E}$ & $\%$ \\
\hline \hline Staph. aureus & 10 & 20 \\
\hline Enteropatogenic E-coli & 8 & 16 \\
\hline Salmonella SPP & 3 & 6 \\
\hline
\end{tabular}

Table (3): Mean Values of the $\mathrm{pH}$ and TVB $-\mathrm{N}$ of The Examined Frozen Chicken Samples.

\begin{tabular}{|c||c|c|}
\hline \multirow{2}{*}{ Samples } & \multicolumn{2}{c|}{ Test } \\
\cline { 2 - 3 } & PH & TVB-N mg/ 100gm \\
\hline \hline Forzen chicken & 5.8 & 20 \\
\hline
\end{tabular}

Table (4): Concentration of Heavy Metals in the Examined Frozen Chicken Samples $(\mathrm{mg} / \mathrm{g})(\mathrm{n}=50)$.

\begin{tabular}{|c|c|c|c|c|}
\hline Metal & CD & $\mathbf{P b}$ & $\mathrm{Cu}$ & Hg \\
\hline Min & 0.01 & 0.006 & 0.375 & 0.08 \\
\hline Max & 0.04 & 0.045 & 2.000 & 0.1 \\
\hline Mean & 0.005 & 0.0022 & 0.954 & 0.085 \\
\hline$\pm \mathrm{SE}$ & 0.004 & 0.022 & 0.170 & 0.004 \\
\hline
\end{tabular}

$\overline{\text { Kafrelsheikh Vet. Med. J. Vol. } 6 \text { No. } 2 \text { (2008) }}$ 


\section{DISCUSSION}

In table (1): showed that the mean values of Total Aerobic Plate Count, Enterobacteriaceae and coliform counts of frozen chicken were $1.6 \times 10^{6}$, $3.3 \times 10^{4}$ and $1.3 \times 10^{3} \mathrm{CFU} / \mathrm{g}$ respectively. Gill et al. (2005) reported that the aerobic plate and coliform counts of chicken were $10^{3}$ and 20 respectively while hassouba et al. (2007) reported that aerobic plate, Enterobacteriaceae and coliform count, in frozen chicken were $2 \times 10^{6}, 2 \times 10^{4}$ and $1.2 \times 10^{3} \mathrm{CFU} / \mathrm{g}$.

Table (2): showed that the incidence of Staph. aureus, Enteropathogenic E.coli and Salmonella of the examined frozen chicken were 20,16 and $6 \%$ respectively. The high level of Staph. aureus growth indicate poor hygiene of handler during the processing stage as well as lack of sterilization of utensils and working surfaces. Staph. aureus produce enterotoxin which lead to food poisoning. Hassouba et al. (2007) recovered 6.7\% Staph. aureus, 4\% Enteropathogenic E.coli from frozen chicken samples examined. In conclusion, frozen chicken samples showed high bacterial loads beside a relatively high rate of the pathogens, this is due to miss-handling and processing as well as the negligence of hygienic aspects at the production level. Therefore, one can safely recommended the following, aiming to have meat with good quality: good hygiene of the meat poultry handlers during the processing stage as well as good sterilization of utensils and working surface. Thermostable of refrigerators and deep freezer is important for retarding the growth of both pathogenic and spoilage bacteria.

Table (3): showed that the mean values of the PH and TVB-N $(\mathrm{mg} / 100 \mathrm{~g})$ of the examined frozen chicken were 5, 8 and 20 respectively. The obtained data are within the permissible limits according to the Egyptian standard, (1991, 2005) (PH is 5.6 - 6.2 and TVB-N is $20 \mathrm{Mg} / 100 \mathrm{~g}$ ). 
Data presented in Table (4): showed that the examined samples had a normal values of $\mathrm{Cd}, \mathrm{Pb}, \mathrm{Cu}$ and $\mathrm{Hg}$ when compaired by FAO/WHO (1972) dietary intake limits (Cd 20-100mg/day, Pb 100mg/ day, cu 15 $\mathrm{mg} / \mathrm{kg}$ and $\mathrm{Hg} 0.03 \mathrm{mg} /$ day). Egyptian Organization for Standardization and Quality Control (E.O.S.Q.C 2360/1993) mentioned that the maximum provisional weekly intake from cadmium by human as 0.0067 $-0.0083 \mathrm{mg} / \mathrm{kg}$ of body weight and $2 \mathrm{mg} / \mathrm{kg}$ of sample weight and from lead by human as $0.05 \mathrm{mg} / \mathrm{kg}$ body weight.

Cadmium $(\mathrm{Cd})$ concentration in frozen chicken in Table (2) ranged from 0.01 to $0.04 \mathrm{Mg} / \mathrm{g}$ with mean value 0.005 . these results agree with those reported by Folandyez/and/Lorenc-Biala (1991), Salisbury et al. (1991) and Hassouba et al. (2007), but lower than that reported by Kienholz et al. (1974) and Daoud et al. (1998).

Lead $(\mathrm{pb})$ concentration ranged from 0.006 to $0.045 \mathrm{mg} / \mathrm{g}$ there results agreed with the results, which reported by Spaulding (1975) and Salisboury et al. (1991) and lower than Folandyez and Lorenc-Biala (1991) and Schiilz-Schroeder (1991).

Copper $(\mathrm{Cu})$ concentration ranged from 0.375 to $2.000 \mathrm{Mg} / \mathrm{g}$ with amean value 0.954. According to the EOSQC (1993) the permissible limit for copper is $15 \mathrm{mg} / \mathrm{kg}$. Copper is known to be essential at low concentrations but it is toxic at high levels. Accordingly, ingestion of an excessive dose of $\mathrm{Cu}$ may lead to severe nausea, bloody diarrhae, hypertension and jundice (Gosel and Bricker,1990).

Mercury $(\mathrm{Hg})$ concentration in chicken samples ranged form 0.08 to $0.1 \mathrm{Mg} / \mathrm{g}$ with mean value of 0.085 . The recorded result of $\mathrm{Hg}$ agreed with those reported by Sell et al. (1975), National Bureau of Standards (1976) and Hassouba et al. (2007). $\mathrm{Cd}, \mathrm{Pb}, \mathrm{Cu}$ and $\mathrm{Hg}$ concentrations in the examined samples were within the permissible limits. 


\section{REFERENCES}

- ATSDR(Agency for Toxic Substances and Disease Regestry)(1990): Toxicological profile for copper. Prepaired by Syracus Research corporation for ATSDR, U.S. public Health Service under contract 880608-2. ATSDR/TP-90-08.

- Bennett, R.W. and lancette, G.A. (2001): Staphylococcus aureus, chapter 12. rev. Jan. 2001. In FDA Bacteriological Analytical Manual $8^{\text {th }}$ ed., Rev. A. AOAC. International Gaithersburg. M.D

- Biotec (1999): Bacterial typing antisera. Biotec. Laboratories Ltd. Ipswich. Suffolk MK.

- Daoud, J.R.; Adel, A.k. and Abou-Bakr, R.M. (1998): Determination of lead, cadmium and copper residues in muscles, liver and kidneys of slaughtered cattle and sheep in El-sharkia Governorate. Vet. Med. J., Giza vol. 46, No,.4. A.pp 339-348.

- Das, A. (1990): Metal ion induced toxicity and detoxification by chelation therapy. In: $1^{\text {st }}$ (ed) A text book on medical aspects of bioinorganic chemistry, CBS, Delhi, P. 17-58.

- Edwards,D.S.;Johston,A.M.and Mead, G.C.(1997): Meat inspection in the M,K: an overview of present practices and future trends. Vet. J. 154: $135-147$.

- Egyptian Organization for Standardization and Quality control (E.O.S.Q.C.)(1993): maximum residue limits for heavy metals in food. Ministry of Industry. No. 2360/1993 PP.5. Cairo. Egypt.

- Egyptian standards (1991): Frozen meat. Number 1522. Egyptian Organization for Standardization and Quality Control. 
- Egyptian standards (2005): Frozen poultry and rabbits. Number 1090. Egyptian organization for standardization and quality control.

- European union communities commission(2001): commossion decision of 8 June 2001 laying down rules for the regular checks on the general hygiene carried out by the operation in establishment according to directive 64/433/EEC on health conditions for the production and masketing of fresh meat Document 2001/ 471/EEC. Off J. EUR communities 21-6-2001-L 165: 48-53.

- FAO (1992): Manual of food quality control. part 4. Food and Agriculture Organization of United Nation, Rome.

- FAO/WHO (1972): Evaluation of Mercury, Lead, Cadmium and the food additives amaranth, diethylpyro carbomate and actyl gallate, WHO food Addetives series No. 4, PP11-56, World Health organization, Geneva.

- Folandyez, J. and lorenc-Biala, H. (1991): Metal in muscle tissue, liver and Kidney of slaughtered animal from the North region of poland. Bromatol. Chem: Toskol, 22: 19.

- Goyer, R.A. (1996): Results of lead research: prenatal exposure and neurological consequences. Environmental Health prespectives 104(10): 1050.

- Gill, C.O.; Badoni, M.; Moza, L.F. ; Barbut, S. and Griffiths, M.W. (2005): Microbiological sampling of poultry carcass portions by excision, rinsing or swabbing. J. food prot. 68 (12): 2718-2720.

- Gossel,T.A.and bricker,J.D. (1990): principels of clinical toxicology. $2^{\text {nd }}$ Ed. Ravent press, New york, pp. 153-192. 
- Hassouba, M.M; Hashim, M.F. and Omiama M. El-Maghraby (2007): Hygienic status and prevelance of heavy metals and pesticides residues in frozen meat, chicken and their products in luxor city. Assiut vet. Med. J.53 (114): 91-105.

- Health Protection Agency (2003 a): Standard methods for food products. Detection of salmonella spp. Standard method F13. Available at Http.www.hpa.org.mk/srm/div-esl-su/sops-docs/ fsops/ F/ 3;/3.pdf. Accessed 26 January 2004.

- Health Protection Agency (2003b): standard methods for food products. Direct enumeration of Escherichia coli standard method F 20. Available at Http.www.hpa.org.mk/srm/div-esl-su/sops-docs/fsops/f/3i/pdf.

Accessed 26 January 2004.

- Honway Loive and Donny Go (1985): Digestion of food samples for total mercury determination. Journal of Association of Official Analytical Chemistry, 68 (5): 891-892.

- ISO (1974): International Standard Organization 2917-1974. meat and meat products: measurement of PH (relerence method). International Standard Organization.

- Kienholz, E.W., Chappell, W.R.; Megan, R.R. and Rudolph, H. (1974): Effects of dietary supplements of copper surface and molybdate upon liver and kidney concentrations of ten minerals in young chickens. Trace subs. In Environ. Health 8:373.

- Lillard,H.S.(1990): the impact of Commercial Processing Procedures on the bacterial contamination and cross contamination of broiler carcasses .J. Food Prot. 53:202-204. 
- Lillard; H.S., Cox, N.A.; Bouley , J.S. and Thomson, J.E (1984): comparison of brands of media for isolating bacteria from poutry, beef and shrimp. J. Food prot.47: 394-397.

- Mert, W. (1987): Trace element in Human and Animal Nutrition. $5^{\text {th }}$ Edn. Vols. I and It London: Academic press.

- Mueller-Hoecker,J.;Meyer,M.; Wiebecke, B. (1988): Copper storage disease of the liver and chronic dietry copper intoxication in two further German infants mimicking Indian childhood cirrhosis. Path. Red. Pract. 183: 39-45.

- National Bureau of Standards, Washington D.C. (1976).

- Notermans; S., Van Leusden. F.M. and Van Schothorst, M. (1977): suitability of different bacterial groups for determining faecal contamination during post scalding stages in the processing of broiler chickens. J. Appl. Bacteriol. 43: 383-389.

- perez, D. (1999): mercury levels in Mole carbs Hipia culebsis, Emerita brasiliensis, E. portoricensis, and lepidopa richmondi (crustancean, Decapoda Hippidae) from a sandy beach at venzuela. Bull Environ. Contam. Toxicol.63:320-326.

- peter, O.N. (1993): Environmental chemistry. $2^{\text {nd }}$ ed. Champan and Hall press. New york pp. 203-221.

- Richard, F. puchyr and Rubin Shapiro, (1986): Determination of trace element in foods by hydrochloride a cid, nitric acid leaching and flame atomic absorption spectroscopy. Journal of Association of official Analytical chemistry, 19(5): 868-870. 
- Salisbury, C.D.C; Chan, W. and Saschenbrecker, P.W. (1991): Multielement concentrations in liver and Kidney tissues from five species of canadion slaughtered animals. J. Assoc. off. Anal- Chem. 74:587-591.

- Sauter, E.A.; Ardrey, W.B. and Petersen, G.F. (1968): Reduction of Shelf-Life of fresh fryers due to injection with E-Coli prior to processing. Poultry Sci. 47:1470-1478.

- Schiilz-schroeder, G. (1991): lead and cadmium in samples of muscles, liver and kidney from lambs and sheep. Fleisch wirtschaft, 71 (12): 1435- 1438.

- Sell, J.l; Dietz, F.O. and Buschellan, M.L. (1975): concentration of mercury in animal products and Soils in North dakota. In archives Environmental contamination and toxicology. Vol. 3, p.278. Springer - verlag, New york.

- Silbergeld, E.K. (1996): the Elimination of lead from Gasoline: Impacts of lead in Gasoline on Human Health, and the costs and benifits of Eliminating lead additives. Draft paper. Washington. DC: The world Bank.

- Spaulding, J.E. (1975): unpublished Data USDA-APHIS, Washington, D.C.

- Tompkin, R.B.(1983): Indicator organisms in meat and poultry products. Food Technol. 37: 107-110.

- Underwood, E.J. (1977): Trace element in Human and Animal nutrition. $4^{\text {th }}$ Ed. Academic press. New york. 


\section{الحالة الصحية وتحديد بعض بقايا المعادن الثقيلة فى الفر اخ المجدة فى مدينة الإسكندرية

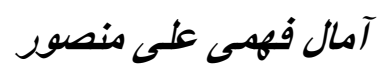 \\ معهد بحوث صحة الحيوان فرع الإسكندرية.}

أجريت هذه الدراسة على عدد خمسون عينة فراخ مجمدة تم تجميعها من محلات أسواق مدينة الإسكندرية فى أماكن مختلفة وخضعت العينات للفحوص الكيميائية والبكتريولوجيه. وكان تركيز الأس الهيدورجينى ونسبة القواعد النيتروجينية الكلية المتصاعدة فى الحدود المسموح بها. وكان متوسط قيم المعادن النقيلة منل الكادميوم والرصاص والنحاس والزئيق 005،، 0022،، 954،، 85.، ميكرو جرام/كجم على الترتيب وهى فى الحدود المسموح بها.

وقد ثم مناقثة الأهمية الصحية والتأثثرات السامة لهذه المعادن الثقيلة وكيفية الحد أو التحكم فى مصادر وصول هذه العناصر إلى الفراخ المجدة. وكان متوسط العد البكتيرى الكلى للميكروبات الهوائية والميكروبات المعوية والميكروبات القولونية فى الدواجن المجمدة 1.6× 610، 3.3×410، 1.3×310 خلية بكتيرية/جرام من العينة على التوالى. وكان تواجد المكور العنقودى الذهبى والإيشيريشيا كولاى المرضية وميكروبات السالمونيلا فى عينات الفراخ المجدة 20، 6،16\% على التوالى حيث أمكن عزل 10 ميكروبات من المكور العنقودى الذهبى و 8 ميكروبات من الإيشيريشبا كولاى و 3 ميكروبات من السالمونيلا. هذا وقد تمت مناقثة الأهية الصحية لهذه الميكروبات المرضية وخطورتها 
على الصحة العامة والطرق الواجب إتباعها للحد من هذه الميكروبات والقضاء عليها وكذلك بقايا المعادن الثقيلة. 